\title{
Decentralization and Service Delivery
}

\author{
Junaid Ahmad \\ South Asia Region \\ World Bank \\ Shantayanan Devarajan \\ South Asia Region \\ World Bank \\ sdevarajan@worldbank.org \\ Stuti Khemani \\ Development Research Group \\ World Bank \\ skhemani@worldbank.org \\ Shekhar Shah \\ South Asia Region \\ World Bank
}

World Bank Policy Research Working Paper 3603, May 2005

The Policy Research Working Paper Series disseminates the findings of work in progress to encourage the exchange of ideas about development issues. An objective of the series is to get the findings out quickly, even if the presentations are less than fully polished. The papers carry the names of the authors and should be cited accordingly. The findings, interpretations, and conclusions expressed in this paper are entirely those of the authors. They do not necessarily represent the view of the World Bank, its Executive Directors, or the countries they represent. Policy Research Working Papers are available online at http://econ.worldbank.org. 


\begin{abstract}
Dissatisfied with centralized approaches to delivering local public services, a large number of countries are decentralizing responsibility for these services to lower-level, locally elected governments. The results have been mixed. This chapter provides a framework for evaluating the benefits and costs, in terms of service delivery, of different approaches to decentralization, based on relationships of accountability between different actors in the delivery chain. Moving from a model of central provision to that of decentralization to local governments introduces a new relationship of accountabilitybetween national and local policymakers-while altering existing relationships, such as that between citizens and elected politicians. Only by examining how these relationships change can we understand why decentralization can, and sometimes cannot, lead to better service delivery. In particular, the various instruments of decentralization-fiscal, administrative, regulatory, market, and financial—can affect the incentives facing service providers, even though they relate only to local policymakers. Likewise, and perhaps more significantly, the incentives facing local and national politicians can have a profound effect on the provision of local services. Finally, the process of implementing decentralization can be as important as the design of the system in influencing service delivery outcomes.
\end{abstract}




\section{Introduction}

In the last quarter century, over 75 countries have attempted to transfer responsibilities of the state to lower tiers of government. Significantly, most of these lower-tier governments have been elected, so that the decentralization is not just administrative or fiscal, but also political. The motivation for the decentralization has varied. In Eastern Europe and the former Soviet Union, it was part of the political and economic transformation; in Latin America, it was to reinforce the transition to democracy; in South Africa, Sri Lanka and Indonesia, it was a response to ethnic or regional conflict; and in Chile, Uganda and Cote d'Ivoire, it was to improve the delivery of basic services (Shah and Thompson 2004). Even when it is not explicit, improving service delivery is an implicit motivation behind most of these decentralization efforts.

The reasons are twofold. First, these basic services, such as health, education, water and sanitation, all of which are the responsibility of the state, are systematically failing - and especially failing poor people (World Bank 2003). That governments are falling short of their responsibility to ens ure adequate health, education, water and sanitation to their people can be seen at various levels. At the macroeconomic level, the main instrument with which governments exercise this responsibility-public spendingseems to have only a weak relationship with outcomes. Public spending on health has no significant association with reductions in child or infant mortality; and public spending on education has an extremely weak relationship with primary school completion rates (Filmer and Pritchett 1999a, 1999b; Filmer, Hammer and Pritchett 2000).

A look at the microeconomic evidence indicates why government spending does not translate to better outcomes. For one thing, the money does not often reach the frontline service provider. In Uganda, the share of nonsalary spending on primary education that actually reached primary schools was 13 percent (Reinikka and Svensson 2001). For another, the quality of these services is often extremely poor. In Bangladesh, the absenteeism rate for doctors in primary health centers was 74 percent (Chaudhury and Hammer 2003).

The second reason why improving service delivery is behind most decentralization efforts is that these services are consumed locally. Historically, they were also provided locally. Norway's health system was run by locally-appointed health commissions until the 1930s; schools in Nepal were managed by communities until the 1960s. Yet today the central government in these two countries (as well as most others) assumes responsibility for the delivery of these services. Many governments and their electorates associate the problems of service delivery with the centralization of these services.

For instance, the fact that only a fraction of the money that is due service providers actually reaches them may be due to the power of the central government vis-àvis local government, through whom the money gets transferred. Similarly, centralization means that the allocation of resources among these local services may not reflect local preferences. Faguet (2001) shows that decentralization in Bolivia led to a better match between local preferences and budgetary allocations. Faguet's study points to another problem of centralization: some regions might get completely neglected. Prior to 
decentralization in Bolivia, an overwhelmingly disproportionate amount of public resources were concentrated in the capital city and its surroundings. Finally, central government provision could also lead to greater corruption and misuse of funds, as the service recipients in a local district cannot monitor the bureaucrat or politician in the capital city (Bardhan and Mukherjee 2000).

However, despite these problems associated with central delivery of services, the experience with decentralization has been quite mixed (World Bank 2003; Burki, Perry, and Dillinger 1999). While success or failure is difficult (and premature) to judge, some common problems associated with decentralization's impact on service delivery have begun to emerge.

The most frequently-cited problem is the lack of capacity at sub-national levels of government to exercise responsibility for public services. In Uganda and Tanzania, the lower tiers of government lacked the ability to manage public finances and maintain proper accounting procedures. Since these were a requirement for transferring money to the lower tiers, they actually received less money than before decentralization. In Uganda, spending on primary health care fell from 33 percent to 16 percent during decentralization (Akin, Hutchinson, and Strump 2001). In Ethiopia, where decentralization goes down to the third tier or woreda level, some woredas lack enough people who can read and write to operate the district governments (Swaroop?).

A second problem is that decentralization has led to misaligned responsibilities, possibly because the process is incomplete, possibly for political reasons. Although Pakistan has devolved responsibility for education to the districts, school teachers remain employees of the provincial government. The district nazim or elected executive has little authority over the hiring, firing, evaluation, or placement of teachers.

Third, while decentralization was in some cases intended to strengthen the political power of lower tiers of government vis-à-vis the center, it has also increased the possibility of political capture within these lower tiers. In 1979, Indonesia established "village governments" with locally-chosen village heads accountable to village councils that would determine budget priorities. A study of 48 rural villages showed that, since village heads chose the members of the council, accountability to the villagers was weak; only 3 percent of the village proposals were included in the district budgets. Those villagers who participated in government organizations were more likely to speak out at village council meetings, crowding out the voice of others in the village (World Bank 2001).

Fourth, a host of other problems, not associated with service delivery, have nevertheless helped to undermine service delivery in decentralizing economies. For instance, the "soft-budget constraint" facing sub-national governments has led to overborrowing (Rodden, Eskeland, and Litvack 2003) and, in the case of Argentina, a major macroeconomic crisis at the end of 2001. The social impact of the Arge ntinian crisis has clearly been a deterioration in service quality: poverty rates jumped 40 percent, 12 percent of the people with formal health insurance discontinued their policies, medical supplies were in short supply throughout the public hospital network and in 2002 a third of the provinces experienced school closings of 20-80 days out of a 180-day school year (World Bank 2003). 
This paper provides a framework that explains both why decentralization can generate substantial improvements in service delivery, and why it often falls short of this promise. The essence of the framework is that the delivery of services requires strong relationships of accountability between the actors in the service delivery chain. In contrast to the delivery of goods or services in a private, competitive market, where the service provider is directly accountable to the client or consumer of the service, the delivery of public services involves at least two relationships of accountability. First, clients as citizens have to hold policymakers or politicians accountable for allocating resources towards these services. Second, policymakers in turn need to hold the service providers accountable for delivering the service. We refer to this as the "long route of accountability," as opposed to the "short route" which is the direct accountability of providers to clients (Figure 1).

Figure 1. The framework of accountability relationships POLICYMAKERS

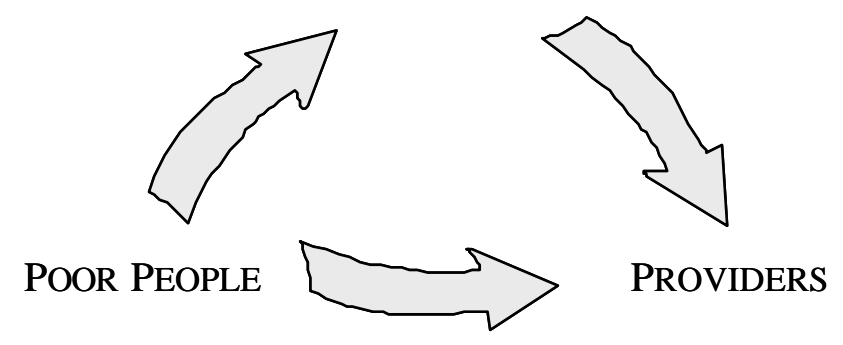

Weaknesses in service-delivery outcomes can be attributed to a breakdown in one or both of the links along the long route of accountability. For instance, the fact that public spending on health and education mainly benefits the non-poor reflects the inability of citizens, especially poor citizens, to hold politicians accountable for resource allocation decisions. In some cases, this is because there is no electoral democracy in the country. In others, there may be a functioning electoral system, but due to information asymmetries or social polarization, the outcomes may still be biased against the poor (Keefer and Khemani 2005). Even if poor citizens can hold politicians accountable, the politician in turn may not be able to hold the provider accountable. The Minister of Education in the capital city will not be able to monitor school teachers in rural primary schools. Unless there is a mechanism by which clients can monitor and discipline the providers (that is, the short-route of accountability is working), the result is that teachers are absent, and primary education suffers. 
These problems with the long route of accountability are what lead some to advocate decentralization as a means of strengthening accountability and thereby improving service delivery. Devolving responsibility for public services to lower tiers of government means that the politician who is responsible is now a locally-elected one (Figure 2). The hope is that this would make him more accountable to the citizens, as they can monitor him more closely and attribute changes in service quality to him more easily. That is, decentralization will strengthen the citizen-local politician relationship of accountability, and thereby the other relationships of accountability for service delivery. ${ }^{1}$

\section{Figure 2. The frame work of accountability relationships under decentralization}

\section{NATIONAL POLICYMAKERS}
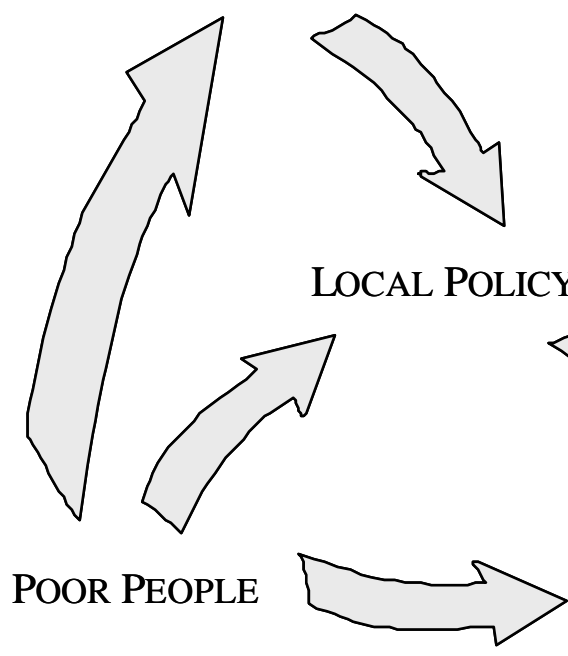

LOCAL POLICYMAKERS

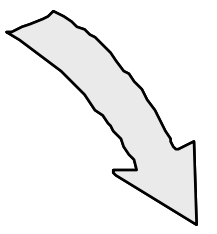

PROVIDERS

However, as shown in Figure 2, decentralization introduces one more relationship of accountability, namely between the central and local policymaker. In fact, much of the literature on decentralization focuses on this relationship - the rules and practices governing fiscal transfers, regulation and expenditures between central and local policymakers. As our earlier discussion pointed out, changes in these rules and practices affect service delivery only through their effect on the accountability relationship between local policymakers and providers. For instance, as mentioned earlier in the case of education in Pakistan, even if devolution leads to fiscal transfers from the central to the local policymakers, but the local policymaker cannot hold the provider accountable (since he is an employee of the central government), the greater accountability of local politicians to their electorate may not result in better service delivery. Section 2 of this chapter examines how different types of accountability mechanisms between central and local government (fiscal transfers, regulation, borrowing rules, etc.) affect the incentives facing service providers, and how these translate to service delivery outcomes.

\footnotetext{
${ }^{1}$ This paper mainly addresses the implications for service delivery of this specific model of decentralization - to locally elected governments. However, in Section 4 we take up the issue of other types of decentralization that might be preferable for improving service delivery.
} 
But even if resources and responsibilities between the central and local governments can be effectively decentralized, there remains the question whether locallyelected governments will have better incentives for service delivery. Section 3 treats this question by examining the effect of decentralization on political incentives at all levelscentral and local. It asks how a system where politicians at the central level were not facing the right incentives to provide good services will change in the wake of decentralization. For instance, if there were information asymmetries, are these reduced or exacerbated by decentralization? How are social polarization and elite capture affected? And how do electoral rules and political institutions affect the outcome?

Finally, in section 4, we explore some open questions in the link between decentralization and service delivery, most of which have to do with the transition from a centralized to a decentralized system. Section 5 concludes.

\section{The Accountability between Central and Local Policymakers and Providers}

Decentralization introduces a new relationship of accountability, that between central and local policymaker (figure 3), even as it seeks to make local politicians more accountable to their local clients. In addressing the difficulties with the "long route of accountability", decentralization introduces its own complications. This section examines how the accountability between central and local policymakers-its fiscal, financing, regulatory, and administrative dimensions - can have an important bearing on the incentives facing service providers and therefore on service delivery outcomes. Sound design and implementation of these aspects of decentralization is the starting point for improving local service delivery.

Figure 3. Accountability relationship between national and local policymakers

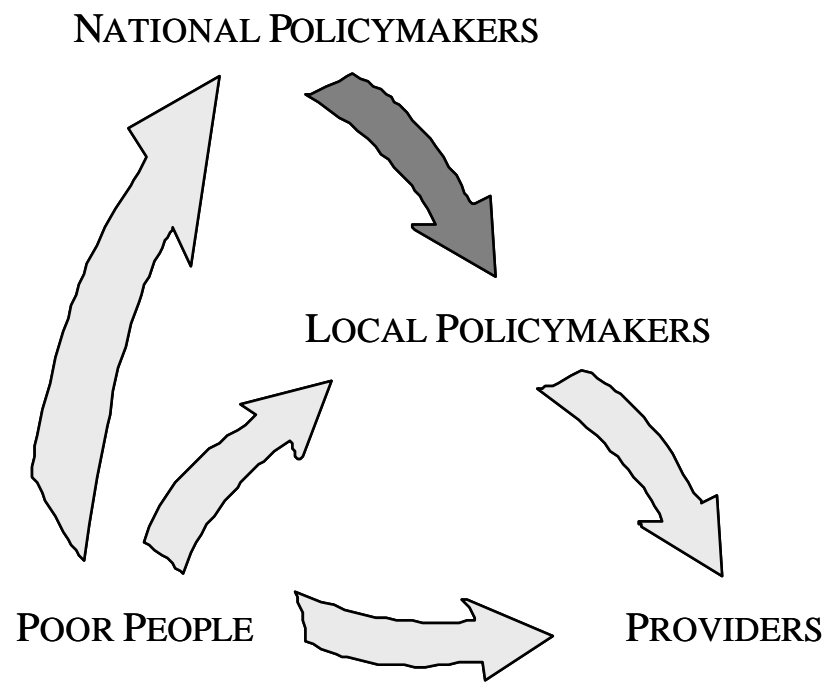




\subsection{Fiscal issues}

Four components define the fiscal dimensions of decentralization: (i) allocation of expenditure responsibilities by central and local tiers of government; (ii) assignment of taxes by government tiers; (iii) the design of an intergovernmental grant system; and (iv) the budgeting and monitoring of fiscal flows between different government tiers. Local governments will be less accountable for delivering good services if they can manipulate these components to shift fiscal liabilities to the center-what is often referred to as a "soft budget constraint" (Litvack, Ahmad, Bird 1998).

The assignment of expenditure and financing responsibility between different tiers of government can have a direct impact on service delivery. For example, in some countries in Latin America, the decentralization of water and sanitation services to small local governments have led to a loss of economies of scale in service delivery (ref: Foster). On the other hand, recognizing that the spillover benefits of health and education outcomes and their impact on equity are national in scope have convinced many governments in Latin America and Africa to keep the financing of these sectors at a central level (Litvack, Ahmad, Bird 1997)). In the United States, the assignment of certain business taxes to local levels have led to inefficient tax competition - a race to the bottom - with consequences for the tax base of municipalities and their ability to finance service delivery (Inman 1992).

In principle, the factors that should come into play in deciding the optimal assignment of expenditure and tax responsibilities include economies of scale, spillover benefits, cost of administering taxes, tax efficiency, and equity. In practice, political realities and historical legacies often determine the choices and, not surprisingly, give rise to mismatches. Political expediency led the Indonesian parliament to hastily pass laws in 1999 to implement a "big-bang," decentralization, but left the expenditure law unclear on assignments. The laws have had to subsequently revised (World Bank 2002).

In addition, the assignment of responsibilities can affect service delivery by altering the accountability of lower- level governments to higher-level governments. For instance, there is often a concurrence in expenditure and financing responsibilities. This issue is well exemplified by the way health and education services are funded and delivered in South Africa. Currently, each of these expenditures is constitutionally considered to be the concurrent responsibility of central and provincial governments. But the concept of concurrence - who is responsible for what aspect of the joint responsibility - has not been defined properly. While policy, delivery standards, and health and education financing are decided nationally, implementation is decentralized to provinces. Not surprisingly, this structure has created incentives for budget gaming. After spending their grants, many provinces leave the central government to worry about any funding gaps, arguing that central mandates need to be financed directly from the center. A system of properly defined concurrent responsibilities might have the center fund national standards, leaving the provinces with own resources to manage and if necessary pay for service delivery above the national minimum standards. Alternatively, responsibilities could be fully centralized with provinces contracted for service delivery through effective monitoring and enforcement mechanisms. 
Second, the accountability of lower-level governments to local clients is enhanced if sub-national governments have access to own-taxes with the right to adjust tax rates. ${ }^{2}$ Indeed, the service delivery incentives facing sub-national governments may improve if, at the margin, they have to raise their own revenues through tax increases rather than relying on central transfers or bailouts that soften the budget constraint. This potential impact of own-taxes suggests that proposals for national tax reforms should include tax instruments that can be devolved, or, at the very least, introduce a system of surcharges on national taxes. ${ }^{3}$ In the United States, the adherence to sales tax as an important source of revenue for states is a reflection of the country's federal origins and a historical commitment to ensure the independence of states in economic management (McLure 1999). South Africa has considered allowing provinces a surtax on national income tax to enable them greater autonomy in decision making. India has considered a dual centerstate VAT (with the power given to states to set rates) in order to strengthen intergovernmental fiscal relations and to enlarge the tax base (Government of India 2004).

Third, the design and implementation of intergovernmental fiscal transfers can influence the accountability of sub-national governments for service delivery. Own-tax sources will rarely meet the funding requirements of sub-national governments, nor does the theory of fiscal decentralization suggest that each tier of government should be selfsufficient. Fiscal transfers typically have a conditional and an unconditional portion. The former leads to a more hierarchical system of accountability - the center holding the subnational accountable for proper use of central transfers. The latter falls in the category of discretionary resources for which sub-national governments are directly accountable to their constituencies. Also critical is the predictability of fiscal transfers, essential in allowing sub-national governments to plan local service delivery more effectively. Predictability is enhanced through the use of formula-based allocation systems driven by simple measures of equity and efficiency (Bird 2003).

In general, the use of unconditional, formula, and block transfers enhances both the predictability and "own revenue" properties of such fiscal flows. However, transfers are also subject to political manipulation by central governments. There is an emerging consensus in the literature that resource distribution across sub-national governments cannot be explained by efficiency and equity considerations alone, that political variables representing the incentives of central political agents are additional and significant determinants. Thus, sub-national governments that are politically disadvantaged, in that

\footnotetext{
2 Even with decentralized tax instruments, administrative costs and efficiently criteria suggest that tax administration and setting of tax bases (as opposed to tax rates) can remain a central function. In many countries, a national but independent tax administration is an option that is being considered as part of the fiscal decentralization process.

${ }^{3}$ This raises several policy issues. For example, if promoting accountability of each tier of government is an important policy objective, the general conclusion that the value-added-tax (VAT) is preferable to a sales tax may need to be reassessed since the VAT is administratively difficult to devolve. Or, to take another example, one would need to reassess whether in a federal system, a combination of central VAT and a provincial sales tax is not "superior" to a central VAT and revenue sharing. In the case of a system of surcharges, national tax reform may also need to consider the coordination or national and sub-national tax rates.
} 
there are weak political incentives for central resource transfer towards them, risk having poor capacity for service delivery. Recent evidence from India shows that even when transfers are supposed to be formula-driven they can be influenced by political concerns and constitutional rules delegating decision-making to independent agencies can make a difference in curbing political influence (Khemani 2003). Several countries, such as India and South Africa, have adopted independent commissions to oversee and protect fiscal transfers from the center to the sub-national from political vagaries. But, the performance of these commissions have been mixed. In the case of India, many states have not implemented state level finance commissions. In South Africa, the Financial and Fiscal Commission, while playing an important role in the initial years of the new democracy, has progressively lost its influence as the country made its transition from conflict years. These examples suggest that the politics that influence the distribution of resources between different tiers of governments may inevitably determine the design and effectiveness of independent commissions aimed at insulating intergovernmental finances from political capture.

Over-dependence on central transfers can also undermine the accountability of sub-national governments to the local electorate, and facilitate shifting of blame for breakdowns in service delivery to upper tiers of government (Rodden 2002; Khemani 2004a). The extent to which the design of intergovernmental transfers affects local accountability depends upon the nature of political relations between national and subnational governments - if institutions of political competition promote accountability to the local electorate, there will be stronger incentives for quality service delivery (Khemani 2004b).

Finally, fiscal interdependence between different tiers of governments means that budgeting and evaluation of transfers are also important elements in ensuring efficient service delivery and getting value for money. In their budgeting process, a number of countries have implemented a medium term expenditure framework (MTEF) that allows sub-national entities to participate in a multi-year budgeting system (e.g., South Africa). Even if the fiscal transfer system does not have a predictable, formula-driven division of total revenues between different tiers of government, the multi-year nature of the MTEF can provide some certainty, usually over a three-year span. To complement its MTEF process, South Africa has introduced a comprehensive Treasury Bill that focuses on financial management within the intergovernmental system, including the regular publication of comprehensive financial information for each tier of government to assist in the monitoring of public resources. This facilitates public monitoring by nongovernmental civil society groups that can make budget information comprehensible to citizens (Singh and Shah 2003). Some countries, such as Brazil, have gone one step further by involving communities in the budget process through a participatory approach such as in city municipalities in Porto Alegre and Belo Horizonte (Andrews and Shah 2003).

\subsection{Financing}

Access to capital markets by sub-national governments is important for several reasons. First, long-term financing is necessary given the lumpiness of public expenditures for infrastructure services and the inefficiency of relying on pay-as-you-go schemes. Without access to long-term finance, investment in infrastructure may be sub- 
optimal. Second, infrastructure investments benefit future generations, so equity requires that future generations should also bear the cost of financing. Financial markets offer this inter-temporal linkage. Third, financial markets play an important role in signaling the performance of regional and local governments. The accountability created for subnational governments on the fiscal side by providing an own-revenue base can be further strengthened by providing access to capital markets on the debt side. In fact, the implicit threat that poor policy management and service delivery may force local policymakers to raise own-taxes, or pay higher borrowing costs, are important incentives in ensuring that service delivery is managed efficiently.

How sub-national governments access financial markets will determine the extent to which such markets will influence the overall health of the subnational government and its ability to ensure good service delivery. Generally, access can be achieved through the central government (where the central government borrows on behalf of sub-national tiers), through a public financial intermediary (e.g., a municipal bank or fund), or by raising funds directly (e.g., commercial bank borrowing or bond operation by subnational governments). While borrowing through the central government certainly guarantees access by sub-national governments to long-term finance, international experience suggests that the allocation of credit through this route may get embroiled in politics. Capital then does not necessarily flow to the most productive use but follows political incentives, with the result that government borrowing is inefficient, the subsequent investments are unproductive, and services suffer. Intermediation by a public financial intermediary (PFI), may also suffer from these drawbacks, with the additional disadvantage that the debt of the PFIs is generally an implicit - hence unplanned -obligation of the central government. In Argentina, for example, public banks provided loans to finance the deficits of sub-national governments, contributing to macro economic imbalances as well as stifling the incentives for changing inefficient service delivery mechanisms (Ahmad 1996).

Direct access to capital markets offers the potential for a more market-based relationship to develop and for a greater chance of enforcing a hard budget constraint. But, moral hazard - the presumption by capital markets that borrowing by sub-national governments will be backed by the central government-can be a concern for decentralized borrowing directly from the market. Resolving this problem is critical for ensuring that financial markets provide the appropriate signals to sub-national governments in their investment decisions.

There are several regulatory mechanisms for reducing the moral hazard problem of decentralized borrowing. Measurement of the assets and liabilities of each tier of government on a regular basis and disclosure of this information is a necessary step. But, it is not sufficient. Explicit measures and mechanisms to manage public sector bankruptcy are essential to ensuring that both sub-national governments and their creditors can be held accountable for their actions without assuming that upper-tier governments will play the role of banker of last resort. In New Zealand, the court system - given its independence and capacity_intervenes in cases of public sector bankruptcy. In the United States, the political process allows the formation of control boards. In both cases, local policy makers have to bear the consequences of poor financial decisions, i.e. face a hard budget constraint. 
An important component of the bankruptcy process is to define a mechanism for ensuring the continuity of a minimum level of service delivery. In principle this can be done by the courts or the control boards with the legal authority to ring fence local resources to maintain local services. This process ensures that the potential spillover effects of a city or local government going bankrupt are internalized and local policy makers are accountable for their decisions. In addition it ensures that services such as water and sanitation and solid waste management, which have important health externalities - and can therefore lead to moral hazard - continue to function.

Other measures include legislating end-of the year balanced budget requirements, eliminating the access by local governments to indirect sources of funding such as using municipal corporations borrowing on behalf of local governments (Brazil) or delaying contribution to pension funds (USA) to finance budgets, or at the very least ensuring that such liabilities are measured and officially reported.

\subsection{Administrative Responsibilities and Building Capacity}

Alongside fiscal and financial resources and autonomy, a key issue facing subnational governments is the access to staff and human resources. Decentralized service delivery is difficult when subnational governments lack skills and institutional capacity. More often than not, administrative decentralization claims far less attention than political and fiscal factors, with decentralization proceeding without explicit staffing strategies or public administration reform. Administrative devolution is inevitably drawn out, often falling behind political and fiscal decentralization. Political and fiscal devolution may have proceeded apace, but administrative changes may only approximate deconcentration (local service providers continue to be full employees of upper-tier government) or delegation (local government has only limited ability to hire and fire providers).

Figure 4. Accountability relationship between policymakers and providers

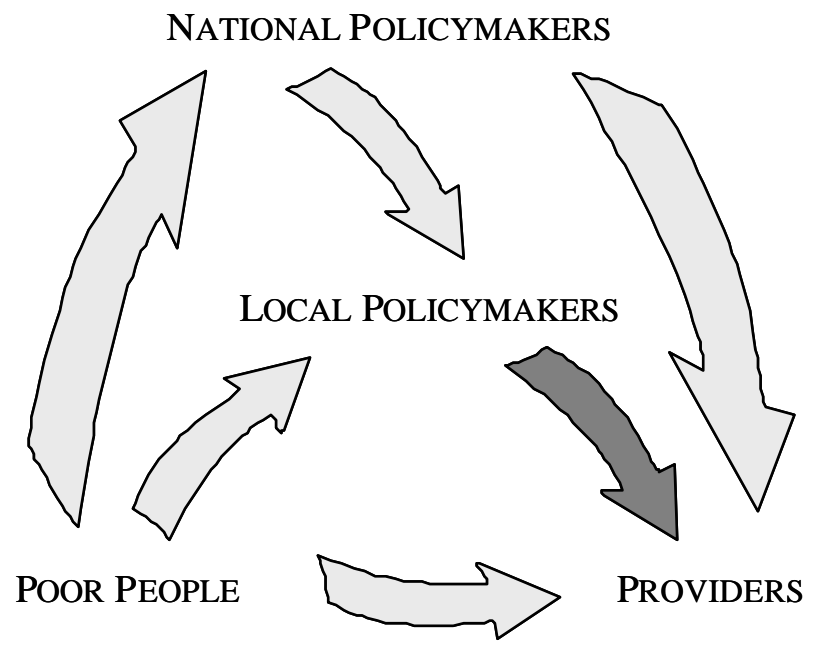

Misalignment between the structure of the government bureaucracy and the assignment of service responsibilities to different tiers confuses incentives, weakens accountability for service delivery, and creates conflicts of interest instead of checks and balances. In many parts of the world-for example, India, Bangladesh, Malawi, and 
Tanzania - administrative staff of sub-national governments are either directly appointed by an upper-tier government or belong to a national service and are on the payroll of the central government. In these cases, local staff continue to respond to the incentives provided by upper-tier governments. In Pakistan, the decentralization to local tiers has been incomplete with local staff still part of a provincial administrative cadre. Their incentive has been to claw back powers from the local level to the provincial one.

The twin tasks of administrative devolution and building local capacity are closely linked, making the task of bringing this alignment about even more daunting. This leads to questions of sequencing between different aspects of decentralization and whether to wait to build local capacity before providing local governments the autonomy to respond to local needs, or to let local autonomy precede the creation of such capacity. There are no one-size-fits-all answers to these difficult questions, but there are some principles dealing with the role of the central government that are worth heeding in implementing decentralization.

The central government has a key role in building local capacity and has two approaches available to it. It can provide training in traditional, top-down ways. Or it can create an enabling environment, using its finance and regulatory powers to help subnational governments define their needs (making the process demand-driven), to deploy training from multiple sources (local, national, overseas, public, private sector), to learn by doing as decentralization proceeds, and to establish learning networks among jurisdictions. This second approach is more consistent with devolution and more likely to produce capacity tailored to the many cross-sector responsibilities of subnational governments. It also avoids the pitfalls of a supply-driven approach. These sequencing issues are also addressed further in Section 4.

\section{Figure 5. Accountability of local policymakers to poor people}

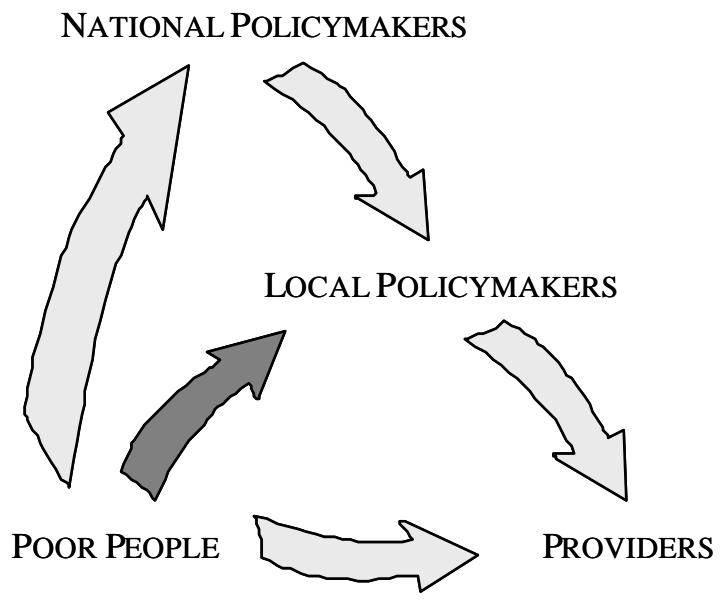




\section{Accountability of Local Governments to Local Citizens}

The hope of decentralization to locally elected governments is that by narrowing the jurisdiction served by a government, and the scope of public activities for which it is responsible, citizens will find it easier to hold government accountable. Roughly speaking, decentralization improves outcomes to the extent that physical proximity increases voter information, participation, and monitoring of performance, and to the extent that narrowing the scope of responsibilities of each tier of government decision makers reduces their ability to shirk on some responsibilities by performing better on others. But in order to fully analyze the question of whether locally elected governments have better incentives for service delivery we must begin with the question of why any level of democratic government in developing countries, where politicians presumably depend upon support from the majority of poor people, fail to provide the basic social services from which poor people benefit. Then we can attempt to understand why the incentives of locally elected governments might be different.

It is a common observation across countries, rich and poor alike, that substantial public expenditures are systematically misallocated, for example to wage bills for bulky state administrations, to farm subsidies that impose distortionary costs on the economy and fail to benefit the poor, and to large infrastructure projects that allow political rent extraction without creating sustainable assets, all at the expense of quality public services. These misallocations have a disproportionate impact on the poor, who are known to benefit from increased access to public services. Even resources allocated to broad public services such as basic education and health might be ineffective in actually delivering those services, if, for example, the posts of teachers and doctors are used to extend the patronage of government jobs, rather than being held accountable for actual service delivery.

Misallocation has persisted despite a sea change in the way in which governments are selected and remain in office. From 1990 to 2000, the number of countries governed by officials elected in competitive elections rose from 60 to $100 .{ }^{4}$ Democratization might be expected to benefit most the "median" or average voter, who in most developing countries is "poor." Yet, public policy in emerging democracies does not seem to have benefited poor voters. Why do policy-makers that depend upon political support from the poor not effectively deliver basic services to the poor?

In recent political economy analysis (Keefer and Khemani 2005), it is argued that imperfections in political markets explain this puzzle. Political market failures in this analysis are reduced to three broad features of electoral competition-one, lack of information among voters about politician performance; two, social and ideological fragmentation among voters that leads to identity based voting and lower weight placed on the quality of public services; and three, lack of credibility of political promises to citizens. Informed voting is costly, and voters may have difficulty in coordinating information to reward (or punish) particular politicians or political parties for specific actions that improve (or worsen) the quality of public services. Similarly, socially and/or

\footnotetext{
${ }^{4}$ According to the number of countries reported in the Database of Political Institutions (Beck et al, 2001) as having competitive elections for executive and legislative office (EIEC and LIEC equal to seven).
} 
ideologically fragmented societies are less able to provide the incentives to their political agents to improve broad public services, because voting is more likely to occur along the dimension of narrowly-defined identities. Even if voters are informed and coordinated in focusing on specific policies, if political competitors cannot make credible promises prior to elections, incumbents are more secure from challenge and have fewer incentives to be responsive to citizens. If politicians are credible only to a few voters, with whom they can maintain clientelist relations, then public resources are allocated to targeted benefits for these "clients", instead of to broad public services.

A strong conclusion of the analysis here, which is difficult for development policy, is that the most adverse effects of political market imperfections are felt in the area of broad public services, such as health and education. It is especially difficult for voters to assess the quality and efficiency of service provision in these areas and to evaluate the responsibility of specific political actors for service breakdowns or poor outcomes. By the same token, political competitors find it especially difficult to make credible promises about service provision. Voters cannot easily collect information that would verify that politicians have fulfilled their promises.

Moreover, even if they could, politicians in many countries can only make credible promises to narrow groups of voters. For these voters, it may be politically more efficient to promise narrow targetable goods - such as a farm subsidy, a contract for an infrastructure project (especially if it doesn't need to get built or if the contractor can get away with using poor quality materials), a government job as a teacher or a doctor (especially if they won't be held accountable to show- up to work in schools and clinics). The large mass of unorganized voters would suffer from the resultant poor quality of services - bankrupt state utilities that bear the subsidy burden, dilapidated roads and undrinkable water, and empty schools and clinics where children don't learn and the sick don't get treated-but would find it difficult to coordinate action to improve political incentives. Social fragmentation in the electorate exacerbates these problems of voter coordination in determining reward and punishment based upon political actions towards the quality of public services.

To the extent that in developing countries, poor voters are more likely to vote in uninformed ways, being susceptible to campaign slogans, or polarized along noneconomic, ideological dimensions such as religion or ethnic identity, and political promises are particularly lacking in credibility or prone to clientelism, it is precisely the broad public services that are likely to suffer.

Within this framework of analysis, decentralization to locally elected governments will improve political incentives and service delivery outcomes if voters are better informed and likely to use information about local public goods in their voting decisions for electing local governments, if there is greater social homogeneity and coordination of preferences for local public goods, and if political promises are more credible at local levels. If political markets function better at more centralized levels of government, then decentralization might not need to be political, but rather designed to help central politicians with agency problems, such as gathering information, monitoring performance, and enforcing norms for locally produced and consumed services. That is, understanding the nature of political market imperfections can help to optimally design 
the institutions of decentralization, or analyze the impact of available and operational institutions.

In the following three sections we consider each political market imperfection in turn, and whether these are likely to be more prevalent for centrally elected rather than locally elected governments. The general answer is, of course, that "it depends", and the objective of the analysis is to begin to list on what this depends.

\subsection{Information, Participation, and Monitoring}

Voters may be better informed about the quality and availability of local public goods because of greater physical proximity, or more focused on using this information in voting decisions because of the narrower range of responsibilities for which to hold their representatives responsible. There are two ideas here, one that information is easier to come by at local levels, and that participation and monitoring by voters is less costly. The other is that if voters care about multiple issues a sub-set of which is decentralized to local levels, then they will be better able to hold each tier of government accountable for their respective responsibilities. For example, if voters care deeply about both education and national defense, national government decision makers can more easily remain in office by doing well on the latter and under-performing on the former. Decentralizing responsibility for education to a lower level government allows voters to hold one set of officials strictly accountable for education and the upper tier strictly accountable for defense.

However, because of historically high degrees of centralization of resources, both public and private, there might not be regular or straightforward channels of information transmission at local levels. For example, information with regard to local policies may be of poorer quality if national newspapers, covering only national issues, are the main source of information for voters. Voters might be more apathetic to participation in local elections, perhaps because of poor media coverage and because they perceive that the bulk of the power and capacity to get things done reside with higher tiers of government. If local expenditures are financed entirely out of grants from higher tiers of governments and not out of local tax bases (as is the case in most developing countries), local voters may have little or no information regarding the resource envelope available to their local government and what those resources are intended to provide.

There is very little data on political participation by households in developing countries so there is very little evidence on relative participation by citizens in local and national politics. Khemani (2001) finds evidence that Indian voters use more information in evaluating governments in state elections than they do in national elections. But, of course, states in India are large enough to be countries in their own right, so it is not clear how much this evidence tells us about real decentralization to local governments.

Chhibber, Shastri, and Sisson (2003) surveyed voters in India and asked which tier of government they held responsible for the public goods they cared most about-medical facilities, drinking water, roads, education. The state governments were indicated as the most responsible agent by the majority of respondents, although locally elected village governments were also indicated as having significant responsibility for these public goods. This evidence suggests that the mere creation of locally elected governments does not ensure that citizens will hold local representatives responsible for public services. 
Azfar and others (2000) find that citizens in the Philippines and Uganda, both countries with recent decentralization reforms, rely on community leaders and local social ne tworks for news about local corruption and local elections, and more on the formal media (TV, radio, newspapers) for news about national elections. However, there is no data about relative quality and range of information from these different sources.

Evidence from Nigeria suggests that local governments' overdependence on central transfers appears to have created uncertainty and lack of information about resources actually available to local governments, which facilitates local evasion of responsibility under the guise of fiscal powerlessness. What local governments do receive as transfers is therefore sometimes treated as the personal fief of local politicians (Khemani 2004a).

\subsection{Social Polarization and Elite Capture}

In socially polarized and/or ethnically fragmented societies, voters tend to vote for those candidates with whom they most closely identify. Political competition between parties thus also concentrates on identity issues, and candidates are nominated from constituencies largely on the basis of demographic calculations of ethnicity and religion. Like uninformed voters, polarized voters are therefore also less able to hold politicians accountable for their overall performance in office in making services work. Public good provision would suffer most under these conditions, since politicians in polarized societies rarely internalize the society-wide costs and benefits of their policy decisions.

Decentralization might help by devolving decision-making authority to more homogeneous groups. However, social homogeneity may decline rather than increase at more local levels. Social polarization between any two local groups may be more intense due to age-old differences across settled communities, and weaker at the national level, perhaps through national campaigns of nation-building. Local politics may therefore be more likely to revolve around identity issues and hence not be geared towards providing strong incentives for political agents to deliver public goods.

If some groups of voters, perhaps the local elite, are more likely to mobilize themselves to influence public policies at more local levels, then decentralization might increase the risk of "capture" of public resources for the benefit of the non-poor (Bardhan and Mookherjee 2000). For this expressed reason, the architects of the Constitution of India, a country with entrenched social and economic inequalities within communities, were reluctant to provide for formal institutions of local government (Mathew and Nayak 1996). There is substantial anthropological and anecdotal evidence from India that disadvantaged groups are systematically excluded from using public goods within their own villages by social processes of discrimination. Micro- level case studies and survey evidence from India show that within-village inequality in education access and achievement is significant, with the privileged castes in the village enjoying nearuniversal adult literacy for several decades while literacy rates are still close to zero among disadvantaged castes in the same village (Drèze and Sen 1996).

Comparing across states in India it appears that local democracy and institutions of decentralization are more effective in states where land reforms and social movements have consciously promoted social egalitarianism (Bardhan 2002). 


\subsection{Credibility of Political Promises}

Political agents at appropriately decentralized levels may have greater credibility to voters at large because of their proximity, or reputation developed through community interactions over an extended period of time. However, these same features may allow clientelist promises to be easier to make and fulfill at more local levels due to closer social relations between the elected representatives and their clients, at the expense of broad public goods.

Keefer (2002) shows that clientelism can be viewed as the natural outcome of political competition when the credibility of political competitors is limited. In these cases, political promises are credible only to "clients." This has clear implications for public policy: the larger the number of clients, the greater the focus of government spending on items targeted to specific individuals (clients) and, ultimately, the less spent on public goods. Compared to a situation where no politicians are credible, clientelism generates less rent-seeking or corruption - but only because instead of keeping resources for themselves, patrons are obligated to transfer the fruits of office to clients.

In an empirical application of his model, Keefer (2002) shows that as democracies age the impetus for clientelist policies first increases - as politicians are likely to increase their credibility first on a targeted basis by increasing the number of their clients - and then declines as broader reputations finally develop. Cons istent with this argument, he finds that corruption and public investment spending (which is more targetable to particular constituencies) are both higher in younger than in older, well established democracies. According to this argument, recently instituted decentralized political competition might take some time to move from clientelistic policies to broad public services, as local political agents develop reputations for providing services to a larger group of the population.

Greater social fragmentation among the electorate might make it more difficult for political agents to make promises about public service provision to large segments of voters, cutting across social divisions. Voters might only believe promises made by candidates belonging to their own ethnic or religious group; those promises are therefore, necessarily narrow, and targeted to members of the respective ethnic groups. A combination of relatively young democratic processes and social heterogeneity at disaggregated levels might therefore create conditions for local politics to be particularly clientelistic. There is some evidence for this, once again from India, from the experience of decentralization to village level governments. India has simultaneously instituted decentralization with political reservations for disadvantaged groups-women, and scheduled castes and tribes-in order to combat the problem of elite capture. Besley and others (2004) find that if the leadership of a locally elected village government in India is reserved for a scheduled caste or tribe member (SC/ST), then SC/ST households residing in the group of villages represented by that government are more likely to receive targeted welfare transfers.

Foster and Rosenzweig (2001) find evidence that is consistent with greater capture and clientelism at local levels. They focus on 3 categories of public goods which together account for 73 percent of the activities of village governments in their sample in India-roads, irrigation, and schools. They find that villages with democratically elected 
governments are more likely to provide more of all three public goods, but the largest effect is for irrigation, as calculated at the sample average, which is the service most likely to benefit the rural elite. However, in villages with a very high proportion of landless (much above the sample average) public investment shifts from irrigation to road construction (rather than education, which is unaffected by proportion landless), which suggests that capture by elites can be ameliorated when the numerical strength of the poor increases, but in a manner that might not be the most efficient for extending benefits to the poor. Roads built by village governments primarily benefit the poor, but largely by raising their (short-term) wages, as local road construction and improvement initiatives in India serve as employment programs for the landless poor. Education, which one expects to have the most profound effect on poverty over the medium and long-term, seems least affected by decentralization.

In a similar vein, in a study of villages in the states of West Bengal and Rajasthan, Chattopadhyay and Duflo (2003) find that villages with women leaders, elected as a consequence of mandated political reservations for women in village governing bodies, are more likely to invest in public goods that are revealed preferred by women during interviews - water, fuel and roads (as it provides employment) and less likely to invest in education. Their findings do not necessarily reflect the success of decentralization, per se, but rather of political reservations at any level of government in environments where there are substantial social pressures operating against the political participation of particular groups.

Taken together, the work on political reservatio ns and village decentralization in India suggests that traditionally disadvantaged groups that receive new democratic privileges tend to exert pressure to shift public resources out of education and into other targeted public goods that provide immediate benefit specifically to their group. While this suggests that political decentralization coupled with political reservations indeed succeeds in giving greater voice to these disadvantaged groups, it is also indicative of problems in the public provision of education services. Mandated reservations might worsen overall public service performance by strengthening clientelist relations and reducing incentives of political competitors to invest in broad policy reputations across the electorate. ${ }^{5}$

\subsection{Political Parties and Electoral Rules}

A problem with large, centralized governments is that resources might be distributed across regions and groups with the purpose of winning only 50 percent of votes, or the required votes from only 50 percent of electoral districts (depending on the nature of electoral laws). Many regions with voters that are not the pivotal or "swing" voters can get systematically and pointedly neglected. Bolivia provides the most dramatic example of this. In 1994, Bolivia created 198 new municipalities where previously none

\footnotetext{
5 The shift away from education may be just a short-term effect of decentralization reforms. The immediate concern of new women political leaders, for example, may be to provide those essential public goods that disproportionately benefit women and have been historically underprovided. Demand for public resources in education may increase with time, as women are better situated to take advantage of improved opportunities. A full analysis of the dynamic impact of political decentralization in India, as the institutions stabilize over time, remains to be undertaken.
} 
existed, and increased the share of national tax revenues going to municipalities from 10 to 20 percent. Before decentralization, about 93 percent of national resources was spent in the nine state or department capitals, while after decentralization this became 38 percent, with a massive shift in resources flowing to the poorest and smallest municipalities (Faguet 2001).

Diaz-Cayeros, Magaloni, and Weingast (2001) find evidence for clientelist spending by the Partido Revolucionario Institucional (PRI) in Mexico to maintain its hegemonic control-non-supporting localities were denied public funds and public employment. They argue that decentralization reduced clientelism as opposition parties in states and municipalities began to publicly clamor for more transparent and egalitarian distribution of national resources.

In general, Seabright (1996) shows theoretically that decentralization can promote accountability by increasing the probability that welfare of a given locality can determine the re-election of government. But decentralization could promote more clientelist spending because there is less electoral gain to be had from providing broad public goods to a larger group of voters. Electoral rules like proportional representation and district magnitude might be more significant determinants of the extent to which governments provide broad public services than institutions of decentralization (Persson and Tabellini 2000).

There is so far very little research into the nature of political institutions at local levels. How do political party systems interact with local electoral politics? One can think of several competing hypotheses. On the one hand, lower barriers to entry in local elections might intensify political competition, break party hegemony, and encourage challengers that are committed to reform. On the other hand, if political parties are the real decision- making bodies rather than individual politicians, it might be that the objective of local government leaders is some thing other than re-election at local levels (which is necessary for accountability to the local electorate). It might be that what political agents care about is rising through the party hierarchy or receiving benefits from party bosses. If this is the objective of locally elected governments, then their political incentives would be no different from the incentives of higher tiers of government. Policies at all levels of government would be determined by the nature of competition between rival political parties. We do not assert nor argue this, but merely point out that decentralization needs to be viewed in the context of broader political institutions that have large implications for service delivery.

\section{Emerging Issues and Policy Implications}

Until now, this paper has discussed the implications of decentralization for service delivery as if decentralization were an outcome. But in reality, decentralization is a process, one that proceeds in fits and starts, occasionally with reversals. Furthermore, the way in which decentralization is carried out - the sequencing, the choice among different forms of decentralization, and how the politics is managed-can be just as important to service delivery as the decision to decentralize itself. This section explores issues associated with the process of decentralization. As there is much less known about the 
implications of these process issues for service delivery, the discussion is speculative, and suggestive of fertile ground for further research.

\subsection{Sequencing Political, Fiscal, and Administrative Decentralization}

Ideally, sub-national governments should first be given clarity about their functions and associated expenditure responsibilities and based on these, the proper assignment and design of tax instruments and transfer systems should be done. The rule that finance follows function appropriately defines this sequencing. In addition, to ensure service delivery and the exercise of devolved powers in general, administrative decentralization should be implemented along with expenditure and fiscal arrangements. So function, finance, and functionaries all need to be sequenced properly.

Once the expenditure, fiscal, and administrative bases are cemented, the rules about market access to finance should be clarified and sub-national borrowing permitted. Setting the expenditure and fiscal framework first before decentralizing borrowing powers is an important rule in the sequencing of decentralization. The expenditure and fiscal base provides the "collateral" to access capital markets: i.e. the fiscal base determines access to finance. In most cases, lack of access to financial markets is not a failure of capital markets but rather simply a failure to provide sub-national governments the appropriate fiscal resources that can be pledged in the capital markets as collateral. In addition, ensuring a proper fiscal base provides a safeguard against creating moral hazard: a policy that enables local governments to borrow in the market in absence of fiscal resources will inevitably signal capital markets that upper-tier governments are responsible for the financial liabilities of lower-tier governments. Similarly, the policy of setting up public financial institutions to overcome the lack of access to capital markets is a step in the wrong direction when the required intervention is on the fiscal side. Under these conditions, capital markets are unlikely to play their role of disciplining local government expenditures and management of services. And local service delivery can suffer.

In reality, only on rare occasions do policy makers have carte blanche--the opportunity to sequence decentralization properly. In South Africa in 1994, the end of the apartheid era allowed the Mandela Government to introduce a new constitution and completely restructure the country's intergovernmental system from scratch. Most countries however do not have such an opportunity to start anew; instead decentralization proceeds as and when there is a political opening. Not surprisingly, decentralization has often led to mismatches with, for example, devolution of expenditure responsibilities outstripping fiscal devolution (e.g., Eastern Europe), expenditure and (some) fiscal decentralization without administrative authority (Pakistan), design of fiscal transfers in the absence of taxing authority and lack of clarity in expenditure (South African provinces), and political decentralization - elections at the local level - without the fiscal authority (India and Bangladesh).

These types of mismatches may result in poor service delivery outcomes, though it is not clear whether the outcomes would necessarily be better without decentralization. More importantly, the mismatches may well provide the political impetus for change. For example, the proliferation of centrally-sponsored development schemes in India with 
overlapping and contradictory objectives is now beginning to create a constituency for their consolidation and simplification. India may well see the shift from uncoordinated vertical schemes to consolidated, cond itional grants that are tied to reforms and to a system eventually of unconditional block grants. Each shift can create the political opportunity for the next shift.

In general, the policy reality that the design and implementation of decentralization is not always systematic suggests that decentralization is not a one-off policy change; it is an on-going process where the end point of accountable and efficient local governments may well take many decades to achieve. In this dynamic and uncertain process, ironically, it is the center that may be best positioned to manage the risks of improper sequencing and their impact. In addition, in such a dynamic process where decentralization processes across countries have different entry points with different mismatches, it is difficult to objectively measure decentralization and its impact. This may account for the dearth of empirical studies on the outcomes of decentralization and it calls into question cross-country econometric comparisons that draw conclusions based on common definitions and measurement of decentralization (Davoodi and Zou 1998). Much more needs to be done to assess the dynamics of decentralization to understand better the costs of inappropriate sequencing, the mismatches that really matter, how the mismatches may or may not provide further impetus to the decentralization process, and most importantly, whether and to what extent services succeed or fail during this dynamic process.

\subsection{Different Forms of Decentralization: Functional versus Jurisdictional}

Various studies have suggested that efficient service delivery requires policy making, service provision, and regulation to be kept separate (World Bank 2003). The problem arises when the roles become blurred with policy makers taking on the role of providers and regulators or when providers are expected to fulfill regulatory functions. In these situations there are no checks and balances and accountability in service delivery diminishes. If separating the functions of policy making, service provision, and regulation within each sector is the key to better service delivery, why have we focused the discussion on the linkage between decentralization of responsibilities to lower tiers of government and service delivery? Would it not have been more logical to discuss how to create separation of functions? For example, it may not matter whether a water utility is owned by a central, state or local government, but whether the water utility has operational independence and autonomy regardless of the tier of government with which it is associated. In other words, the issue for service delivery may not be jurisdictional decentralization - separation of powers between tiers of government - but functional decentralization - separation of powers between government and service provider.

There are several reasons why functional decentralization by itself does not allow us to address the problem of service delivery. To begin with, we face a political reality that service responsibilities have been devolved to lower-tier governments in many countries. In this context, "getting the rules right" about decentralization is essential to improving service delivery. In addition, services that require the implementation of user charges or allocation of subsidies- both being political acts - cannot be isolated from the politics of local governments. Inevitably, local governments will be drawn into the 
process i.e. functional decentralization cannot in reality be kept separate from the politics of subnational governments. In Cochabamba in Bolivia water supply was privatized and the formal private provider was given exclusive rights and allowed to implement user charges in an area dominated by local independent providers. Given the local politics of water this led to riots in the streets and the cancellation of the contract (Nickson and Vargas 2002).

More importantly, jurisdictional decentralization may well be the political path for catalyzing functional decentralization. At one level, by devolving powers to subnational governments an upper-tier government can play an independent role in supporting incentives for lower tiers to reform their service delivery. In South Africa, for example, the central government has implemented a conditional grant aimed at providing incentives for reform of urban services for large cities after having devolved powers to city governments (Ahmad 1996). In the United States, given that municipalities have devolved authority over service delivery, state governments can credibly play the role of an independent regulator. In contrast, in Indian states, the fragmentation of responsibilities between states and municipalities has created a situation whereby policy makers at the state level have very little incentive to devolve powers to providers or local governments. Their incentive is to centralize, thus preserving their power base.

In addition, during the process of devolution - the transition period between centralized to decentralized systems - upper-tier governments have the chance to enforce functional decentralization at the sub-national level. For example, in Pakistan the federal government has offered fiscal incentives to the provinces to restructure their education services. During an early stage of decentralization when sub-national governments may not have the requisite capacity and there are political incentives to show success in service delivery, such fiscal incentives can provide the incentives for sub-national governments to restructure their services in ways that separates policy making, provision and regulatory functions.

\subsection{Decentralization to Community-based Organizations}

Decentralization of management authority down to the level of service providers and communities through the creation of community-based organizations with representation of service providers and users, such as education, health, water committees, is being explored as a promising approach to improving services. The hope is that it will institutionalize the participation of beneficiaries in the management of services and thereby improve performance. There are at least two problems with this decentralization strategy. The one that has received the most attention in the literature is that of "capture" of these organizations by local elite who would use them for their own benefit. If local communities have entrenched inequalities, such decentralization might facilitate elite domination of public services and systematic exclusion of disadvantaged groups. Baland and Platteau (1999) explore the role of inequality in the local management of resources. Mansuri and Rao (2003) provide a review of the empirical evidence on the functioning of community based and managed projects, distinguishing between the roles of elites as benevolent facilitators versus pernicious captors of resources. These studies indicate that while local community organizations would have informational advantages to identify the poor, there is typically a strong role for 
centralized governments to devolve project funding in a way that creates the right incentives for local agents to properly target benefits to the poor.

The second set of problems derive directly from political incentives of governments. O ne is in implementation - if truly egalitarian community based organizations were successfully created and invested with the authority of managing service providers, rewarding them for good performance and punishing them for service breakdowns, politicians would have to give-up their claim on public employment as a form of political patronage. If politicians don't give up this claim then local communities would have a hard time making service providers like teachers and doctors respond to their pressures- these providers may simply ask to be transferred out of the demanding communities, and refuse to take certain postings, because they know their jobs are politically protected. Poor people might indeed be well aware that providers are not doing their job, but feel powerless to change anything because teachers and doctors are elite members of the community, or people with political connections. Drèze and Gazdar (1996) recount how village schools in the state of Uttar Pradesh in India can be non-functional for as long as ten years due to teacher absenteeism and shirking, or used as a cattle-shed by the village head-man, without any collective protest being organized.

In a multi-tier structure of government, the institution of decentralization to community based organizations might create opportunities for higher tier governments to use these groups to bypass democratically elected go vernments in middle and lower tiers, and target benefits to individuals or groups that are critical to win political power (not necessarily the poorest nor the most deserving). That is, it is difficult to get away from the impact of overall political incentives facing elected representatives at any tier of government.

\subsection{Managing the Politics of Decentralization}

Even if decentralization is aimed at improving service delivery, it will be resisted by those who have benefited from the previously centralized system. For instance, politicians and bureaucrats at upper tiers of government may have been earning rents from the system that gave them control over the allocation of resources. These groups will resist decentralization if it threatens their access to such rents. This creates at least two dilemmas facing decentralizing societies.

First, during the early phases of decentralization, as lower-tier governments adapt to their new responsibilities, the results in terms of service delivery may be disappointing. How can we distinguish between weak outcomes because of the transition and weak outcomes because of a fundamental flaw in the design of decentralization? In addition, decentralization opponents can use any early disappointing outcomes to build political momentum to slow down or even reverse decentralization. If the problem is one of transition, then how can these political forces be balanced by those who favor decentralization, even if they have little to show for it at the start? One obvious approach to managing the politics of decentralization is try to show early results on service delivery.

This leads to a second dilemma. In order to show early results, it may be necessary to intervene and provide resources and technical assistance to lower-tier governments in ways that are different, and perhaps even inimical, to the long-run, 
sustainable success of decentralized service delivery. For instance, in Pakistan decentralization to districts is based on resources being transferred by the newlyconstituted Provincial Finance Commissions. Yet these commissions are only beginning to develop the award mechanisms for transferring resources in ways that will yield results. There are other ways of transferring resources that are likely to generate better outcomes in the short run, but these would involve going around the Provincial Finance Commission's formulae and the philosophy of Pakistan's decentralization. This is a classic dilemma in development, between short-term results and long-term institutionbuilding, and it is reflected particularly sharply in the process of decentralization. There is clearly no simple answer to this dilemma, except to reemphasize the principle of "strategic incrementalism" - reforms that are not likely to fully address service delivery difficulties but can alleviate acute problems while creating the conditions for deeper and more favorable change. This can be contrasted with, for lack of a better term, "incremental incrementalism" that merely solves one set of immediate problems but creates others, as might happen when donors continue to fund central, verticallyorganized development schemes to deal with the immediate service deficits but that crowd out local initiative or accountability.

Another insight emerging from the framework of accountability presented in this chapter is that if the evolving institutions of decentralization address political market imperfections, even if accidentally, and not purposefully designed to do so, then they have enormous potential to eventually change the incentives of elected representatives to improve service delivery. In this view the progress in decentralization in any particular local context could be analyzed in terms of its impact on information and participation of citizens, and the credibility of political agents when making promises about improving broad public services, even if actual gains in service delivery are not immediately forthcoming. For example, even with incomplete decentralization of service delivery resources and responsibilities, if the creation of locally elected governments is instrumental in mobilizing poor citizens to participate in political processes and increase monitoring of government performance, then this might improve the incentives of higher tiers of government that retain control over service delivery.

\section{Concluding Remarks}

Dissatisfied with centralized approaches to delivering local public services, a large number of countries are decentralizing responsibility for these services to lowerlevel, elected governments. The results have been mixed. This chapter has provided a framework for evaluating the benefits and costs, in terms of service delivery, of different approaches to decentralization. We highlighted the fact that service delivery depends on the relationships of accountability of different actors in the delivery chain.

Decentralization introduces a new relationship of accountability-between national and local policymakers-while also altering existing relationships, such as that between citizens and elected politicians. Only by examining how these relationships change can we understand why decentralization can, and sometimes cannot, lead to better service delivery. In particular, the various instruments of decentralization-fiscal, administrative, regulatory, market, and financial—can affect the incentives facing service providers, even though they relate only to local policymakers. Likewise, and perhaps more 
significantly, the incentives facing local and national politicians can have a profound effect on the provision of local services. Finally, the process of implementing decentralization can be as important as the design of the system in influencing service delivery outcomes.

Two of the more significant shifts in the $21^{\text {st }}$ century have been the increased attention to the delivery of public services on the one hand, and greater decentralization of responsibility for these services on the other. This chapter has attempted to identify the linkages between these two phenomena, emphasizing that the relationship is complex and far from being fully understood. Yet countries are taking decisions that affect the welfare of millions of people, many of them poor. The challenge to researchers is to provide the knowledge base so that these decisions will improve the welfare of these poor people.

\section{References}

The word "processed" describes informally reproduced works that may not be commonly available through library systems.

Ahmad, Junaid 1996. "The Structure of Urban Governance in South African Cities." International Taxation and Public Finance 3(2): 193-213.

Akin, John, Paul Hutchinson and Koleman Strumpf, 2001. "Decentralization and Government Provision of Public Goods: The Public Health Sector in Uganda." Abt Associates: MEASURE Evaluation Project Working Paper No. 01-35, Bethesda, MD.

Andrews, Matthew, and Anwar Shah. 2003. "Towards Citizen-oriented Local-level Budgets in Developing Countries." In Anwar Shah, eds., Ensuring Accountability When there is No Bottom Line. Washington,D.C.: World Bank.

Azfar, Omar, Satu Kahkonen, and P. Meagher, 2000. "Conditions for Effective Decentralized Governance: A Synthesis of Research Findings.” Working Paper, IRIS Center, University of Maryland, College Park MD

Baland, Jean Marie and Jean-Philippe Platteau, 1999. The Ambiguous Impact of Inequality on Local Resource Management." World Development 27(5): 773-88

Bardhan, Pranab, 2002. "Decentralization of Governance and Development." Journal of Economic Perspectives 16(4): 185-205.

Bardhan, Pranab, and Dilip Mookherjee, 2000. "Capture and Governance at Local and National Levels." American Economic Review, 90(2): 135-39

Beck, Thorsten, George Clarke, Alberto Groff, Philip Keefer and Patrick Walsh, 2001. "New Tools in Comparative Political Economy: The Database of Political Institutions," World Bank Economic Review 15(1): 165-76

Besley, Timothy, Rohini Pande, Lupin Rahman, and Vijayendra Rao, 2004. "The Politics of Public Good Provision: Evidence from Indian Local Governments." Journal of the European Economic Association, April-May 2004

Bird, Richard M. 2003. Subnational Revenues: Realities and Prospects, reading for course on Intergovernmental Fiscal Relations \& Local Financial Management, 
World Bank Institute, World Bank, Washington DC. http://www1.worldbank.org/wbiep/decentralization/Topic07_Printer.htm.

Bird, Richard M. 1999. "Rethinking Tax Assignment: The Need for Better Subnational Taxes," Draft paper, Fiscal Affairs Department, International Monetary Fund.

Burki, Shaid Javed, Guillermo Perry, and William Dillinger 1999. Beyond the Center: Decentralizing the State. World Bank: Washington, D.C.

Chattopadhyay, R. and E. Duflo 2003. "Women as Policy Makers: Evidence from a India-Wide Randomized Policy Experiment.” MIT Department of Economics, Working Paper.

Chaudhury, Nazmul and Jeffrey S. Hammer 2003. "Ghost Doctors: Absenteeism in Bangladeshi Health Facilities." Background Paper for World Development Report 2004.

Davoodi, Hamid and Heng-fu Zou. 1998. "Fiscal Decentralization and Economic Growth: A Cross-Country Study.” Journal of Urban Economics 43.

Diaz-Cayeros, Alberto, Beatriz Magaloni, and Barry Weingast, 2001. "Democratization and the Economy in Mexico: Equilibrium (PRI) Hegemony and its Demise." Stanford University. Processed.

Drèze, Jean and Amartya Sen 1996. Indian Development: Selected Regional Perspectives, New Delhi: Oxford University Press

Drèze, Jean and Haris Gazdar 1996. "Uttar Pradesh: The Burden of Inertia." In Drèze, J. and A. Sen (eds.) Indian Development: Selected Regional Perspectives. Oxford University Press.

Faguet, J. 2001. "Does Decentralization Increase Responsiveness to Local Needs? Evidence from Bolivia.” Policy Research Working Paper No. 2516, The World Bank, Washington, D.C.

Filmer, Deon and Lant H. Pritchett, 1999a. "The Impact of Public Spending on Health: Does Money Matter?" Social Science and Medicine 49(10): 309-23.

Filmer, Deon and Lant H. Pritchett 1999b. "The Effect of Household Wealth on Educational Attainment: Evidence from 35 Countries." Population and Development Review 25(1): 85-120.

Filmer, Deon, Jeffrey S. Hammer and Lant H. Pritchett 2000. "Weak Links in the Chain: A Diagnosis of Health Policy in Poor Countries." World Bank Research Observer 17(1) 47-66.

Foster, A. and M. Rosenzweig 2001. "Democratization, Decentralization, and the Distribution of Local Public Goods in a Poor Rural Economy.” Working Paper, Brown University, http://adfdell.pstc.brown.edu/papers/democ.pdf.

Government of India 2004. Report of the Task Force on Implementation of the Fiscal Responsibility and Budget Management Act, 2003. Ministry of Finance, Government of India, July 2004. 
Inman, R. P. 1992. "Can Philadelphia Escape Its Fiscal Crisis With Another Tax Increase?" Business Review of the Federal Reserve Bank of Philadelphia, SeptOct, 5-20.

Keefer, Philip, and Stuti Khemani, 2005. "Democracy, Public Expenditures, and the Poor.” World Bank Research Observer, Forthcoming, Spring 2005

Keefer, Philip 2002. "Clientelism, Credibility and Democracy.” World Bank, Development Research Group, Washington, D.C. Processed.

Khemani, Stuti, 2004a. "Local Government Accountability for Service Delivery in Nigeria.” World Bank, Development Research Group, Washington, D.C. Processed.

Khemani, Stuti, 2004b. "Partisan Politics and Fiscal Discipline in a Federation: Evidence from the states of India." World Bank, Development Research Group, Washington, D.C. Processed.

Khemani, Stuti, 2003. "Does Delegation of Fiscal Policy to an Independent Agency Make a Difference? Evidence from intergovernmental trans fers in India." World Bank, Development Research Group, Washington, D.C. Processed.

Khemani, Stuti, 2001. "Decentralization and Accountability: Are voters more vigilant in local than in national elections?" Policy Research Working Paper 2557. World Bank, Washington, D.C.

Litvack, Jennie, Junaid Ahmad, and Richard Bird. 1998. Rethinking Decentralization in Developing Countries. Washington, D.C.: World Bank.

Mansuri, G. and V. Rao. 2003. "Community Based (and Driven) Development: A Critical Review." World Bank Research Observer 19(1): 1-33.

Mathew and Nayak, 1996. "Panchayats at Work." Economic and Political Weekly, July 6, 1996, page 1765 .

McLure, Charles E., Jr. 1999. "The Tax Assignment Problem: Conceptual and Administrative Considerations in Achieving Subnational Fiscal Autonomy," Presented to Seminar on Intergovernmental Fiscal Relations and Local Financial Management organized by National Economic and Social Development Board of the Royal Thai Government and the World Bank, Chiang Mai, Thailand, February 24-March 5.

http://www1.worldbank.org/wbiep/decentralization/Topic06_Printer.htm

Nickson, Andrew, and Claudia Vargas. 2002. "The Limitations of Water Regulation: The Failure of the Cochabamba Concession in Bolivia." Bulletin of Latin American Research 21(1):99-120.

Persson, Torsten and Guido Tabellini 2000. Political Economics: Explaining Public Policy. Cambridge, MA: The MIT Press

Pradeep Chhibber, Sandeep Shastri, and Richard Sisson, 2003. "The State, Voluntary Associations, and the Provision of Public Goods in India." Department of Political Science, University of California at Berkeley. Processed. 
http://www.polisci.berkeley.edu/Faculty/bio/permanent/Chhibber,P/publicGoods. pdf

Reinikka, Ritva and Jakob Svensson, 2001. "Explaining Leakage in Public Funds," Policy Research Working Paper No. 2709, World Bank, Washington, D.C.

Rodden, Jonathan, Gunnar Eskeland, and Jennie Litvack. eds. 2003. Decentralization and Hard Budget Constraints. Cambridge, Mass.: MIT Press.

Rodden, J., 2002. "The dilemma of fiscal federalism: intergovernmental grants and fiscal performance around the world." American Journal of Political Science 46(3): 670-687

Seabright, Paul, 1996. "Accountability and Decentralization in Government: An Incomplete Contracts Model." European Economic Review 40(1): 61-89

Shah, Anwar and Theresa Thompson, 2004. "Implementing Decentralized Local Governance: Treacherous Road with Potholes, Detours and Road Closures." Policy Research Working Paper 3353. World Bank, Washington, D.C.

Singh, Janmejay, and Parmesh Shah. 2003."Making Services Work for Poor People: The Role of Participatory Public Expenditure Management." Background note for the WDR 2004.

World Bank 2003. World Development Report 2004: Making Services Work for Poor People, World Bank and Oxford University Press, Washington, D.C.

World Bank, 2002. "Decentralizing Indonesia: A Regional Public Expenditure Review, Overview Report." East Asia, World Bank, Washington, D.C. Processed.

World Bank 2001. "Indonesia Poverty Report.” World Bank: Washington, D.C. 